\title{
The Fisher Hypothesis and Investment Assets: The Vietnamese and Thai
}

\section{Case}

\author{
Dalina Amonhaemanon ${ }^{1,2}$, Jan Annaert ${ }^{1,3}$, Marc J.K. De Ceuster ${ }^{1,3}$ \& Hau Le Long ${ }^{1,4}$ \\ ${ }^{1}$ Universiteit Antwerpen, Prinsstraat 13, 2000 Antwerpen, Belgium \\ 2 Prince of Songkla University, Trang, Thailand \\ ${ }^{3}$ Antwerp Management School, Sint-Jacobsmarkt 9, 2000 Antwerpen, Belgium \\ ${ }^{4}$ Cantho University, Cantho city, Vietnam
}

Correspondence: Dalina Amonhaemanon, Universiteit Antwerpen, Prinsstraat 13, 2000 Antwerpen, Belgium \& Prince of Songkla University, Trang, Thailand. E-mail: Dalina.a@psu.ac.th

Received: July 31, 2014

doi:10.5430/ijfr.v5n4p180
Accepted: October 7, $2014 \quad$ Online Published: October 14, 2014

URL: http://dx.doi.org/10.5430/ijfr.v5n4p180

\begin{abstract}
Following the approach of Fama and Schwert (1977), we investigate the inflation hedging ability of stocks, gold and real estate for Vietnam and Thailand. We estimate the relationship between their returns and various inflation measures (actual inflation, expected inflation as well as unexpected inflation) on both monthly and quarterly data. We do not find statistical support for the Fisher effect, due to the large standard errors. Still, from a short term qualitative point of view, both gold and real estate qualify more as a potential inflation hedge than stocks.
\end{abstract}

Keywords: Vietnam, Thailand, inflation, stock returns, gold returns and real estate returns

\section{Introduction}

Fisher (1930) postulated that expected nominal interest rates should move one-for-one with expected inflation. Fama and Schwert (1977) noticed that this so-called Fisher hypothesis can be extended to all investment assets. As claims against real assets, common stocks should compensate investors for movements in inflation (Lintner, 1975). Besides common stock, also real estate and gold are traditionally viewed as (potential) hedges against inflation and other forms of uncertainty (Chua and Woodward, 1982). Due to its positive correlation with inflation, real estate has been regarded as one of the most powerful inflation hedges (Fogler, Granito and Laurence, 1985; Ganesan and Chiang, 1998; Glascock, Feng, Fan and Bao, 2008; Sing and Low, 2000) Demand for gold is reported to increase as expected inflation rises (Moore, 1990). Alan Greenspan - the former Chairman of the Federal Reserve Board - cited gold as a "store of value measure which has shown a fairly consistent lead on inflation expectations and has been over years a reasonably good indicator" in his speech before the U.S. Congress on February 22, 1994. (Note 1)

Despite popular beliefs, the hedging ability of investment assets tends to vary strongly across countries and depends on macroeconomic conditions (Chua and Woodward, 1982; Taylor, 1998). Since any evidence for Vietnam and Thailand is lacking, we fill this gap. We investigate the relationship between stock returns and expected as well as unexpected inflation for both countries. Next, we examine the relationship between the two components of inflation and the most popular investment assets in these countries: gold for Vietnam and real estate for Thailand.

Vietnam presents a unique case in the world because gold is used as a substitute of the national currency (VND) (Vuong, 2004). Commercial banks grant loans in both the national currency and in gold. Real estate prices are commonly set in terms of gold. One-third of the Vietnamese people invest in gold. It is estimated that, on a per-capita-income basis, Vietnam consumes twice as much gold as India and 10 times that of China. (Note 2) Vietnam is the eighth among the 10 countries that imported the largest quantity of gold in the world in 2010. (Note 3) The total reserve of gold in Vietnam is, according to the World Gold Council, about 1,000 tons; meanwhile, a famous British precious metals research consultancy (GFMS, Ltd.,) estimated that this amount is at least 460 tons. With respect to these figures, the total reserve of gold in Vietnam accounts for approximately around $21-45$ billion USD, equivalent to $20-45 \%$ of GDP, which is fairly high relative to $40 \%$ of GDP of the food and food services industries of the country. There are about 7,000 - 10,000 gold trading counters and companies with 10 gold trademarks nationwide. (Note 4) Apart from the inherent role of gold for Vietnamese people, the country's affinity 
for gold is also due to its history of hyperinflation, e.g., up to more than hundreds of percent per year over the 1980s-1990s. Taking all these facts into account, gold could be an important asset hedging against inflation in Vietnam.

As for Thailand, real estate plays an important role in the economy since its holdings make up a significant portion of total household assets. Subhanij (2009) estimated that the residential and commercial real estate account for more than $33.3 \%$ of total households' assets and that real estate debts contribute approximately $30 \%$ of the aggregate households' debts. These facts indicate the potential importance of real estate in hedging against inflation in Thailand.

This study contributes to the existing literature in a number of ways. First, it improves our understanding about the relationship between stock returns and inflation in emerging markets. Given thin trading, lower trading volumes and possibly less informed and less rational investors than in more developed markets Spyrou (2004) concluded that this relationship for most of the emerging stock markets may be substantially different. Furthermore, the study also enriches the literature with the hedging ability of gold and real estate against inflation in developing countries. Finally, the study can be used by the policy makers as the theoretical background in formulating policies to attract more capital inflows into the country (Mahmood and Dinniah, 2009).

The remainder of the paper is structured as follows. Section 2 reviews the existing literature. In section 3, we develop our testable hypotheses. We present the methodology used in section 4. Section 5 describes the data and their descriptive statistics. Empirical results are discussed in section 6. Finally, we conclude.

\section{Literature Survey}

\subsection{Stock Returns and Inflation}

Empirical studies on the relationship between stock returns and inflation were initially conducted for the U.S. and other industrialized nations using different periods and stock prices indices. The findings were remarkably mixed. Some studies showed a negative or no relationship, e.g., Cohn and Lessard (1981) for 8 OECD countries, Gultekin (1983) for 25 countries, Solnik (1983) for 9 OECD countries, etc). Other results pointed to a positive or no relationship between nominal stock returns and inflation rates, e.g., for the U.K. (Boudoukh and Richardson, 1993; Firth, 1979). Focusing on the long-run relationship between stock returns and inflation, it was found to be positive (Kim and Ryoo (2011) for U.S. data in the 1950s, Engsted and Tanggaard (2002) for the U.S. and Denmark, negative (e.g., Najand and Noronha (1998) for Japan, Crosby (2001) for Australia) or not existing (Ely and Robinson (1997) for international data, (Floros, 2008; Hondroyiannis and Papapetrou, 2006) for Greek data).

For developing countries, the empirical findings do not show more coherence. Chatrath, Ramchander and Song (1997) found a negative relationship between stock returns and inflation for India. This result was supported by Zhao (1999) for China, Khil and Lee (2000) for 10 out of 11 Pacific-rim countries except Malaysia and Omran and Pointon (2001) for Egypt. On the contrary, Choudhry (2001) found a positive relationship between stock returns and inflation in high inflation countries, i.e., Argentina, Chile, Mexico and Venezuela. Likewise, examining the relationship for 10 emerging stock markets, Spyrou (2004) corroborated the positive relationship for Chile, Mexico, Brazil, Argentina, Thailand, South Korea, Malaysia, Hong Kong, Philippines and Turkey during 1990s. The Fisher hypothesis is also supported by Alagidede (2009) for several African countries, namely, Egypt, Kenya, Morocco, Nigeria, South, Africa and Tunisia.

\subsection{Gold and Inflation}

According to Chua and Woodward (1982), the demand for gold can be classified into two categories: demand for consumption and investment. Regarding to its latter role, gold is traditionally viewed as a hedge against inflation and other forms of uncertainty. Chua and Woodward (1982) is one of the early studies of gold's inflation hedge capacity, protecting investors against both expected and unexpected inflation in six major industrial countries over the period 1975-1980. They found that while, in the short-run, gold could effectively hedge against inflation for the U.S., it was not systematically related to inflation for the other countries (Canada, Germany, Japan, Switzerland and the U.K.). In the same strand, some studies examined the relationship between gold price and general level of prices (Ghosh, Levin, Macmillan and Wright, 2004; Harmston, 1998; Laurent, 1994). These studies showed that gold acts as an effective long-run hedge for inflation in the U.S., the U.K., France, Germany and Japan. The results for the U.S. are also supported by Taylor (1998) over period 1914-1937, Worthington and Pahlavani (2007) for the period 1945-2006 and Adrangi, Chatrath, \& Raffiee (2003) for the period 1968-1999. Similarly, examining the determinants of gold price fluctuations over the period 1976-2005, Levin, Montagnoli and Wright (2006) indicated a significant long-run 
relationship between the gold price and the U.S. price level, supporting the belief that gold is a long-run hedge against inflation in the U.S.

\subsection{Real Estate and Inflation}

Real estate has historically been regarded as one of the powerful hedge assets against inflation since it is highly positive correlated with inflation (Fogler, Granito and Laurence, 1985; Ganesan and Chiang, 1998; Glascock, Feng, Fan and Bao, 2008; Sing and Low, 2000). Many authors have studied this conjecture empirically. For the U.S., Fama and Schwert (1977) found that, over 1953-1971, real estate returns move one-for-one with inflation rates. Similarly, evidence for real estate as a good hedge against expected inflation is also documented by others for the U.S., e.g., among others, (Brueggeman, Chen and Thibodeau, 1984; Charles, Glenn and Donna, 1991; Hartzell, Hekman and Miles, 1987). Hoesli (1994) claims that the Swiss real estate market provides a better hedge against inflation than common stocks in the long term. Stevenson and Murra (1999) also documented the long-term hedging potential against inflation of property for the Irish market. Several studies revealed that real estate provides an attractive hedge against inflation for Asian markets. Among others, Sim and Choe (2002) found that the housing market in South Korea can hedge against both actual and expected inflation. Similarly, Sing and Low (2000) showed that property could offer a better hedge against inflation than other financial assets in Singapore.

Following the approach of Fama and Schwert (1977), Miles (1996) concluded that the returns on commercial property in the U.K. are too sensitive to economic conditions to be a good hedge against inflation. Barber, Robertson and Scott (1997) found that commercial real estate could partially hedge against inflation. Its hedging capacity to unexpected inflation was found to be superior as compared to hedging the expected component.

In contrast, some studies claim that real estate provides an ineffective hedge against inflation. For instance, Hamelink and Hoesli (1996), analysing the Swiss market, claim that stocks and bonds outperform real estate as an hedging instrument. Chu \& Sing (2003) concluded that none of the property types examined, is a good hedge against inflation, neither in the long nor in the short run. This finding is also supported by Ganesan and Chiang (1998) for the Hong Kong market. Again we can conclude that property market returns may be a good hedge against inflation in some regions and time periods.

It is clear from this short literature overview that the empirical evidence is inconclusive and that the puzzle of the inflation-asset return relationship is all but solved (Al-Khazali and Pyun, 2004; Hondroyiannis and Papapetrou, 2006). Extrapolating results from one country to another seems to be virtually impossible. Hence, there is a need for Vietnamese and Thai policy makers to gain acquaintance with the hedging ability of investment assets for their specific countries.

\section{Methodology}

\subsection{The Fisher Hypothesis}

Fisher (1930) states that the expected nominal interest rate is equivalent to the sum of the expected real interest rate and the expected inflation rate, and also that the real and monetary sectors of the economy are largely independent. Therefore, the expected inflation rate should be fully reflected into the expected nominal interest rate. The theory is generalized to nominal returns on any asset, which should move one-for-one with expected inflation (Fama and Schwert, 1977). Formally, the proposition can be represented by

$$
\left[1+E_{t-1}\left(R_{t}\right)\right]=\left[1+E_{t-1}\left(r_{t}\right)\right]\left[1+E_{t-1}\left(\pi_{t}\right)\right],
$$

where $E_{t-1}$ is the conditional expectation operator at time $t-1 ; R_{t}$ denotes the nominal return on an asset from time $t-1$ to $t ; r_{t}$ is the appropriate equilibrium real return on the asset from time $t-1$ to $t$ and $\pi_{t}$ represents the inflation rate from time $t-1$ to $t$.

Equation (1) can be equivalently reformulated as

$$
E_{t-1}\left(R_{t}\right)=E_{t-1}\left(r_{t}\right)+E_{t-1}\left(\pi_{t}\right)+E_{t-1}\left(r_{t}\right) E_{t-1}\left(\pi_{t}\right) .
$$

In (2), the cross-product term $E_{t-1}\left(r_{t}\right) E_{t-1}\left(\pi_{t}\right)$ is usually negligible. Hence, the representation of (2) is routinely as

$$
E_{t-1}\left(R_{i t}\right)=E_{t-1}\left(r_{i t}\right)+E_{t-1}\left(\pi_{t}\right) \text {. }
$$

\subsection{Empirical Model}

Since the main goal of the paper is to investigate the inflation-hedging properties of stocks, gold and real estate, we first investigate the ex post relationship between the actual nominal asset return of stocks, gold, real estate and inflation using the following regression: 


$$
R_{t}=\varphi+\omega \pi_{t}+\epsilon_{t},
$$

where $\varphi$ and $\omega$ are coefficients and $\epsilon_{t}$ is the error term.

Following (Fama and Schwert, 1977), we also estimate the following ex ante model in the second step:

$$
R_{t}=\alpha+\beta E_{t-1}\left(\pi_{t}\right)+\gamma U E_{t-1}\left(\pi_{t}\right)+n_{t},
$$

where $n_{t}$ is the error term.

Since both explanatory variables are orthogonal, consistent estimates of $\beta$ and $\gamma$ can be obtained as long as expected inflation is observable. In equation (5), Fama and Schwert (1977) indicate three cases for the hedging potential of an asset: The asset is said to be a complete hedge against expected inflation $(\beta=1.0)$ : there exist a one-to-one relationship between the nominal return on asset and the expected inflation rate, and the expected real return on the asset varies independently to the expected inflation rate. If the tests show that $\gamma=1.0$, the asset is $a$ complete hedge against unexpected inflation. The asset is considered as a complete hedge against inflation ( $\beta=\gamma=1.0)$,: the nominal return on asset has a one-to-one relationship with both the expected and unexpected inflation rate, and the ex post real return on the asset varies independently to the ex post inflation rate.

It should be noted that this approach requires a suitable measure for the expected and unexpected inflation rates. Traditionally, the treasury bill rate was used as a proxy for expected inflation (Fama and Schwert, 1977). Due to a lack of traded short-term risk-free monetary instruments in Vietnam, we have to resort to an alternative proxy for the expected inflation. Although at least four inflation forecasting methods are suggested in the literature i.e. time series-based models, a Phillips curve-based model, a term structure-based model, and survey-based measures such as surveys by Livingston, SPF or Michigan, (Ang, Bekaert and Wei, 2007), the availability of data leads us to use ARIMA models (Box and Jenkins, 1970) to proxy the expected and unexpected inflation. Although ARIMA models are probably not the first best solution, they are commonly used by others (Gultekin, 1983; Li, Narayan and Zheng, 2010; Wahlroos and Berglund, 1986).

We estimate all regressions by OLS, since our focus is to examine the short-run influence of inflation on the asset returns, and not the feedback from returns to inflation. We use the White (1980) heteroscedasticity-consistent covariance matrix to obtain consistent and most efficient estimates.

\section{Data and Summary Statistics}

This study uses monthly time series data of the consumer price index (CPI), stock indices and the gold price index for both countries and quarterly data for the Thai real estate index. For Vietnam, the Hochiminh stock index (VNI) is provided by the Hochiminh stock exchange (HOSE) for the period 2000M7-2011M12. The Vietnamese gold price index (GOLD) is reported by the Vietnam General Statistics Office (GSO) for the 2001M1-2011M12 period. The Thai Stock Exchange index (SET) is obtained from Datastream for the 1987M2-2011M12 period. The single-detached house with land index (S_REAL) and the town house with land index (T_REAL) are provided by the Bank of Thailand for the 1993Q1-2011Q4 period. The Consumer Price Index of both countries, Vietnam (VCPI) and Thailand (TLCPI), is obtained from Datastream. Stock indices are end-of-the-month values. All variables are defined as log changes. All returns and inflation rates are stationary according to the (not reported) ADF and the KPSS tests. (Note 5)

Summary statistics for all variables are presented in Table 1. (Note 6) The stock returns of both countries show an almost identical and positive mean return. Thai real estate average returns are smaller and the gold index of Vietnam even indicates negative average returns over the sample period. As usual the standard deviations are high compared to the average returns. The distribution of all variables can be characterized as negatively skewed and leptokurtic, especially substantially high kurtosis is observed for the Thai real estate returns. The mean and median inflation rates for both countries are relatively close to each other. 
Table 1. Summary statistics

The table reports the summary statistics for all variables. The asset returns are denoted by $R$. Subscripts of the asset returns are composed of an asset indicator ( $S$ for stocks, $G$ for gold, $R S$ for single detached houses and $R T$ for town houses) and an indicator of the country (TL for Thailand and VN for Vietnam). $\pi_{\mathrm{TL}}$ denotes the Thai inflation rate; $\mathrm{E}(\pi)$ and $\mathrm{UE}(\pi)$ are the expected and unexpected inflation rates. Subscripts denote the country. All returns at time $t$ are calculated by changes in log of the index from time ( $t-1)$ to $t$. Inflation rates at time $t$ are defined as changes in log of the Consumer Prices Index from time ( $t-1)$ to $t$. Expected and unexpected inflation rates of both countries are decomposed from the actual inflation rates by using Autoregressive (AR) models, where expected inflation rates are the linear prediction of the AR model and unexpected inflation rates are the residuals of the AR model. For monthly inflation rates, Vietnam $\left(\pi_{t}=0-0.2049 \pi_{t-1}-0.1097 \pi_{t-11}+0.4916 \pi_{t-12}\right)$ and Thailand $\left(\pi_{t}=\right.$ $\left.0.0014+0.2779 \pi_{t-1}+0.0325 \pi_{t-11}+0.2240 \pi_{t-12}\right)$; For quarterly inflation rates, Vietnam $\left(\pi_{t}=0.0006-0.4787 \pi_{t-3}\right)$ and Thailand $\left(\pi_{t}=0.0068+0.2526 \pi_{t-4}\right)$.

Panel A. Monthly data

\begin{tabular}{|c|c|c|c|c|c|c|c|c|c|c|c|}
\hline \multicolumn{8}{|c|}{ THAILAND } & \multicolumn{4}{|c|}{ VIETNAM } \\
\hline & & $\mathrm{R}_{\mathrm{STL}}$ & $\pi_{\mathrm{TL}}$ & $\mathrm{E}(\pi)_{\mathrm{TL}}$ & $\mathrm{UE}(\pi)_{\mathrm{TL}}$ & & $\mathrm{R}_{\mathrm{SVN}}$ & $\mathrm{R}_{\mathrm{GVN}}$ & $\pi_{\mathrm{VN}}$ & $\mathrm{E}(\pi)_{\mathrm{VN}}$ & $\mathrm{UE}(\pi)_{\mathrm{VN}}$ \\
\hline Mean & & 1.01 & 0.30 & 0.30 & 0.00 & & 1.09 & -0.02 & 0.00 & 0.00 & 0.00 \\
\hline Median & & 1.66 & 0.27 & 0.30 & 0.00 & & -0.06 & 0.51 & 0.09 & 0.02 & -0.04 \\
\hline Min & & -36.86 & -3.06 & -0.57 & -3.19 & & -42.06 & -21.96 & -2.98 & -1.82 & -2.19 \\
\hline Max & & 35.47 & 2.62 & 0.93 & 2.07 & & 32.58 & 11.52 & 1.86 & 1.05 & 1.86 \\
\hline Std & & 9.92 & 0.54 & 0.21 & 0.50 & & 12.02 & 4.41 & 0.80 & 0.51 & 0.65 \\
\hline Skewness & & -0.34 & -0.46 & -0.18 & -0.56 & & -0.17 & -1.42 & -1.24 & -1.07 & -0.22 \\
\hline Kurtosis & & 5.03 & 9.39 & 4.77 & 9.34 & & 3.82 & 8.38 & 6.05 & 5.85 & 3.85 \\
\hline $\mathrm{N}$ & & 299 & 299 & 287 & 287 & & 137 & 131 & 137 & 125 & 125 \\
\hline \multicolumn{12}{|c|}{ Panel B. Quarterly data } \\
\hline & \multicolumn{6}{|c|}{ THAILAND } & \multicolumn{5}{|c|}{ VIETNAM } \\
\hline & $\mathrm{R}_{\mathrm{STL}}$ & $\mathrm{R}_{\mathrm{RSTL}}$ & $\mathrm{R}_{\mathrm{RTTL}}$ & $\pi_{\mathrm{TL}}$ & $\mathrm{E}(\pi)_{\mathrm{TL}}$ & $\mathrm{UE}(\pi)_{\mathrm{TL}}$ & $\mathrm{R}_{\mathrm{SVN}}$ & $\mathrm{R}_{\mathrm{GVN}}$ & $\pi_{\mathrm{VN}}$ & $\mathrm{E}(\pi)_{\mathrm{VN}}$ & $\mathrm{UE}(\pi)_{\mathrm{VN}}$ \\
\hline Mean & 3.01 & 0.40 & 0.44 & 0.91 & 0.91 & 0.00 & 3.24 & -0.06 & 0.02 & 0.03 & 0.00 \\
\hline Median & 2.82 & 0.75 & 0.59 & 0.90 & 0.90 & 0.05 & 1.26 & 0.34 & 0.10 & -0.03 & -0.01 \\
\hline Min & -54.99 & -23.26 & -21.72 & -4.13 & -0.37 & -5.15 & -71.61 & -14.34 & -1.94 & -1.07 & -1.52 \\
\hline $\operatorname{Max}$ & 60.14 & 19.94 & 18.05 & 4.98 & 1.93 & 3.85 & 61.93 & 11.99 & 2.36 & 0.99 & 1.96 \\
\hline Std & 18.67 & 4.51 & 3.90 & 1.16 & 0.30 & 1.14 & 26.33 & 5.01 & 0.79 & 0.38 & 0.71 \\
\hline Skewness & -0.19 & -4.49 & -4.34 & -0.46 & -0.46 & -0.67 & -0.10 & -0.42 & -0.12 & 0.21 & 0.40 \\
\hline Kurtosis & 3.75 & 32.23 & 30.74 & 7.04 & 7.01 & 7.52 & 4.01 & 3.76 & 3.91 & 3.99 & 3.25 \\
\hline $\mathrm{N}$ & 100 & 75 & 75 & 100 & 96 & 96 & 46 & 44 & 46 & 43 & 43 \\
\hline
\end{tabular}

\section{Empirical Results}

\subsection{Regression Results}

Table 2 presents the regression results on a monthly frequency. Regressions are performed on individual inflation rates up to 4 periods, and on multiple inflation rates to capture the importance of individual terms while controlling for the others.

Panel A shows the regression results for Thai and Vietnamese stock returns. As can be seen, the coefficient on the contemporaneous inflation rate is consistently negative in all regressions for the stock returns of both countries. Yet, no coefficients are statistically significant, except at the $10 \%$ level in regression equation (c) for Thailand. For Thai stock returns, the negative coefficient on lagged terms is consistently observed in most cases, whereas most of coefficients on lead terms are positive. The consistently negative coefficient for the lagged inflation terms in Thailand is difficult to reconcile with the Fisher hypothesis. For Vietnamese stock returns, positive coefficients are found in most of the cases, both for lead and lagged terms of inflation. Especially, the coefficient for the 4 periods lagged inflation is significantly positive and greater than 1.0. This means that it takes a relatively long time for the market to react against information on inflation. It also indicates that it might be beneficial to also study the relationship on a quarterly frequency. 
Assuming that all past information up to time $t-1$ is fully incorporated by the market at time $t$, the sum of coefficients in equation (b) should reflect the actual relationship between expected nominal stock returns and expected inflation. The regression results show a negative, albeit not significant, relationship between Thai stock returns and inflation. In contrast, the sum of the coefficients in equation (b) indicates a positive relationship greater than 1.0 between stock returns and inflation for Vietnam. Nevertheless, all the coefficients on lag 1 to lag 3 are not statistically significant and the overall result is obviously influenced by the coefficient on lag 4 .

Table 2. Regression results of monthly stock returns, gold returns on actual inflation

The table reports the regression results between monthly stock returns, gold returns and actual inflation rates. In the table,

$\mathrm{R}_{\mathrm{STL}}$ denotes the stock returns of Thailand; $\mathrm{R}_{\mathrm{SVN}}$ symbolizes the stock returns of Vietnam; $\mathrm{R}_{\mathrm{GVN}}$ is the gold returns of Vietnam; $\pi_{\mathrm{t}}$ is the actual inflation rate at time t. The coefficients $\left(\beta_{i k}\right)$ are shown with the robust $\mathrm{t}$-values in the parentheses. $(* * *),(* *)$ and $(*)$ indicate significance at the $1 \%, 5 \%$ and $10 \%$ levels, respectively. Simple regressions takes the form: $R_{i t}=\alpha_{i}+\beta_{i k} \pi_{t+k}+\varepsilon_{t}$. Multiple regressions can be represented as: $(a) R_{i t}=\alpha_{i}+\sum_{k=0}^{-4} \beta_{i k} \pi_{t+k}+\varepsilon_{t}$; (b) $R_{i t}=\alpha_{i}+$ $\sum_{k=-1}^{-4} \beta_{i k} \pi_{t+k}+\varepsilon_{t} ;(c) R_{i t}=\alpha_{i}+\sum_{k=0}^{+4} \beta_{i k} \pi_{t+k}+\varepsilon_{t} ;(d) R_{i t}=\alpha_{i}+\sum_{k=-4}^{+4} \beta_{i k} \pi_{t+k}+\varepsilon_{t}$.

Panel A. Regression results of monthly stock returns on actual inflation rates.

\begin{tabular}{|c|c|c|c|c|c|c|c|c|c|c|}
\hline \multirow{3}{*}{$\begin{array}{c}\text { Leads } \\
\text { /lags } \\
(\mathrm{k})\end{array}$} & \multirow{3}{*}{$\begin{array}{c}\text { Simple } \\
\text { Regressions } \\
\beta_{i k}\end{array}$} & \multicolumn{4}{|c|}{ Thailand stock index returns $\left(\mathrm{R}_{\mathrm{STL}}\right)$} & \multirow{3}{*}{$\begin{array}{c}\text { Simple } \\
\text { Regressions } \\
\beta_{i k}\end{array}$} & \multicolumn{4}{|c|}{ Vietnam stock index returns $\left(\mathrm{R}_{\mathrm{SVN}}\right)$} \\
\hline & & \multicolumn{4}{|c|}{ Multiple regressions $\beta_{i k}$} & & \multicolumn{4}{|c|}{ Multiple regressions $\beta_{i k}$} \\
\hline & & (a) & (b) & (c) & (d) & & (a) & (b) & (c) & (d) \\
\hline \multirow[t]{2}{*}{4} & 0.3337 & & & -0.0543 & -0.1359 & -1.0062 & & & -1.1072 & -0.3618 \\
\hline & -0.35 & & & $(-0.05)$ & $(-0.14)$ & $(-0.76)$ & & & $(-0.79)$ & $(-0.26)$ \\
\hline \multirow[t]{2}{*}{3} & 1.3662 & & & 1.0474 & 1.1085 & 0.6044 & & & 0.1846 & 0.5902 \\
\hline & -1.19 & & & -0.89 & -0.88 & -0.43 & & & -0.12 & -0.38 \\
\hline \multirow[t]{2}{*}{2} & 1.1082 & & & 0.6092 & 0.5465 & -0.7131 & & & -0.4557 & 0.0111 \\
\hline & -0.88 & & & -0.52 & -0.41 & $(-0.48)$ & & & $(-0.29)$ & -0.01 \\
\hline \multirow[t]{2}{*}{1} & 0.8568 & & & 1.1927 & 1.2032 & 0.9952 & & & 0.8481 & 0.7658 \\
\hline & -0.6 & & & -1.01 & -0.85 & -0.66 & & & -0.51 & -0.43 \\
\hline \multirow[t]{2}{*}{0} & -1.4263 & -1.2992 & & $-1.9398 *$ & -1.8609 & -0.3199 & -0.6541 & & -0.2599 & -0.4489 \\
\hline & $(-1.06)$ & $(-0.87)$ & & $(-1.72)$ & $(-1.25)$ & $(-0.23)$ & $(-0.41)$ & & $(-0.18)$ & $(-0.26)$ \\
\hline \multirow[t]{2}{*}{-1} & -0.9941 & -0.475 & -0.8731 & & -0.2764 & -0.8657 & -1.0284 & -0.7691 & & -0.826 \\
\hline & $(-0.83)$ & $(-0.32)$ & $(-0.67)$ & & $(-0.20)$ & $(-0.69)$ & $(-0.67)$ & $(-0.56)$ & & $(-0.50)$ \\
\hline \multirow[t]{2}{*}{-2} & -0.5092 & -0.5547 & -0.4956 & & -0.6566 & 0.6816 & 1.0326 & 1.1741 & & 0.9624 \\
\hline & $(-0.28)$ & $(-0.25)$ & $(-0.23)$ & & $(-0.30)$ & -0.56 & -0.64 & -0.76 & & -0.57 \\
\hline \multirow[t]{2}{*}{-3} & 0.5017 & 1.0828 & 1.0376 & & 1.1681 & 0.4992 & 1.7473 & 1.7649 & & 1.7818 \\
\hline & -0.53 & $(-0.95)$ & -0.92 & & -1.02 & -0.45 & -1.13 & -1.16 & & -1.12 \\
\hline \multirow[t]{2}{*}{-4} & -0.9042 & -1.1909 & -1.1615 & & -1.1172 & $2.3803 * *$ & $3.0659 * *$ & $3.1421^{* *}$ & & $3.0169 * *$ \\
\hline & $(-0.92)$ & $(-1.21)$ & $(-1.15)$ & & $(-1.17)$ & -2.27 & -2.43 & -2.58 & & -2.22 \\
\hline \multirow[t]{2}{*}{$\alpha_{i}$} & & $0.0175^{* *}$ & $0.0146^{*}$ & 0.0077 & 0.0103 & & 0.0069 & 0.0069 & 0.0119 & 0.0071 \\
\hline & & -2.01 & -1.95 & -0.92 & -0.9 & & -0.67 & -0.67 & -1.11 & -0.66 \\
\hline$N$ & 295 & 299 & 299 & 295 & 295 & 133 & 133 & 133 & 133 & 129 \\
\hline $\bar{R}^{2}$ & 0 & 0.01 & 0.01 & 0.02 & 0.02 & 0 & 0.05 & 0.04 & 0.01 & 0.05 \\
\hline$F$ & 0.13 & 0.92 & 0.79 & 1.03 & 1 & 0.58 & 1.78 & 2.13 & 0.3 & 0.92 \\
\hline
\end{tabular}


Table 2. Regression results of monthly stock returns, gold returns on actual inflation (Continued)

\begin{tabular}{|c|c|c|c|c|c|}
\hline \multirow{3}{*}{$\begin{array}{l}\text { Leads/lags } \\
\text { (k) }\end{array}$} & \multicolumn{5}{|c|}{ Vietnam gold index returns $\left(\mathrm{R}_{\mathrm{GVN}}\right)$} \\
\hline & \multirow{2}{*}{$\begin{array}{c}\text { Simple } \\
\text { regressions }\left(\beta_{i k}\right)\end{array}$} & \multicolumn{4}{|c|}{ Multiple regressions $\left(\beta_{i k}\right)$} \\
\hline & & (a) & (b) & (c) & (d) \\
\hline \multirow[t]{2}{*}{+4} & $0.7101 * *$ & & & $0.8604 * *$ & $0.7973 *$ \\
\hline & $(2.02)$ & & & (2.24) & (1.93) \\
\hline \multirow[t]{2}{*}{+3} & -0.4345 & & & 0.2195 & 0.2501 \\
\hline & $(-1.19)$ & & & $(0.45)$ & $(0.52)$ \\
\hline \multirow[t]{2}{*}{+2} & $0.9326^{* *}$ & & & $1.1411^{* *}$ & $1.0927^{*}$ \\
\hline & $(2.06)$ & & & $(2.00)$ & $(1.95)$ \\
\hline \multirow[t]{2}{*}{+1} & -0.2412 & & & 0.1408 & 0.1697 \\
\hline & $(-0.64)$ & & & $(0.33)$ & $(0.35)$ \\
\hline \multirow[t]{2}{*}{0} & 0.0428 & 0.0314 & & 0.1656 & 0.1314 \\
\hline & $(0.10)$ & $(0.06)$ & & $(0.35)$ & $(0.23)$ \\
\hline \multirow[t]{2}{*}{-1} & 0.3004 & 0.0111 & -0.0013 & & -0.0403 \\
\hline & $(0.75)$ & $(0.02)$ & $(-0.00)$ & & $(-0.07)$ \\
\hline \multirow[t]{2}{*}{-2} & -0.7784 & -0.8129 & -0.8196 & & -0.6902 \\
\hline & $(-1.48)$ & $(-1.26)$ & $(-1.35)$ & & $(-1.04)$ \\
\hline \multirow[t]{2}{*}{-3} & 0.0688 & -0.1519 & -0.1527 & & -0.0818 \\
\hline & $(0.09)$ & $(-0.18)$ & $(-0.18)$ & & $(-0.09)$ \\
\hline \multirow[t]{2}{*}{-4} & 0.2688 & 0.1668 & 0.1632 & & 0.1487 \\
\hline & $(0.49)$ & $(0.28)$ & $(0.29)$ & & $(0.28)$ \\
\hline \multirow[t]{2}{*}{$\alpha_{i}$} & & -0.0002 & -0.0002 & 0.0004 & 0.0004 \\
\hline & & $(-0.06)$ & $(-0.06)$ & $(0.12)$ & $(0.11)$ \\
\hline$N$ & 127 & 131 & 131 & 127 & 127 \\
\hline $\bar{R}^{2}$ & 0.02 & 0.02 & 0.02 & 0.06 & 0.08 \\
\hline$F$ & 4.09 & 0.63 & 0.78 & 2.31 & 1.83 \\
\hline
\end{tabular}

Panel B reports the regression results of monthly gold returns of Vietnam. Unlike the results for stock returns, the coefficient on contemporaneous inflation term is positive in all cases. Three out of four coefficients on inflation terms in regression equation (b) are negative and statistically insignificant. As a result, their sum is also negative. On the other hand, regression coefficients for the lead terms consistently indicate a positive and statistically significant relation at lead-2 and 4. While the significance of the lead-4 coefficient is difficult to interpret in economic terms, that of lead-2 coefficient is more intuitive in the Vietnamese context. The historical hyperinflation of the country has arguably created inflationary awareness among the people. Therefore, any information or even speculation about future inflation irrespective of its sources can be quickly incorporated into the gold market. Moreover, like other countries, the General Statistics Office of Vietnam (GSO) has customarily released the CPI with a delay up to 3 weeks or even later than the underlying month, at a moment when the people already know most information. 
The regression results for quarterly stock, gold and real estate returns on actual inflation rates are shown in Table 3.

Table 3. Regression results of quarterly stocks returns, real estate returns, gold returns on actual inflation rates

The table reports the regression results of quarterly stock returns, gold returns, real estate returns on actual inflation rates at the contemporaneous term as presented below for convenience. In the table, $\mathrm{R}_{\mathrm{STL}}$ denotes the stock returns of Thailand; $\mathrm{R}_{\mathrm{RSTL}}$ is the returns on single-detached house of Thailand; $\mathrm{R}_{\mathrm{RTTL}}$ is the returns on town houses with land of Thailand; $\mathrm{R}_{\mathrm{SVN}}$ symbolizes the stock returns of Vietnam; $\mathrm{R}_{\mathrm{GVN}}$ is the gold returns of Vietnam; $\pi_{\mathrm{t}}$ is the actual inflation rate at time t. $(* * *),(* *)$ and $(*)$ indicate significance at $1 \%, 5 \%$ and $10 \%$ levels, respectively. The robust $\mathrm{t}$-values are shown in the parentheses.

\begin{tabular}{lccccc}
\multicolumn{7}{c}{$R_{i t}=\alpha_{i}+\beta_{i} \pi_{t}+\varepsilon_{t}$} & & & \\
\hline & $\left(\alpha_{i}\right)$ & $\left(\beta_{i}\right)$ & 100 & 0.00 & 0.03 \\
\hline $\mathrm{R}_{\mathrm{STL}}$ & 0.0329 & -0.3065 & & & \\
& $(1.20)$ & $(-0.17)$ & 75 & 0.01 & 1.55 \\
$\mathrm{R}_{\mathrm{RSTL}}$ & -0.0070 & 0.6347 & & & \\
& $(-0.57)$ & $(1.24)$ & 75 & 0.01 & 1.45 \\
$\mathrm{R}_{\mathrm{RTTL}}$ & -0.0055 & 0.5568 & & & \\
& $(-0.53)$ & $(1.20)$ & 46 & 0.00 & 0.02 \\
$\mathrm{R}_{\mathrm{SVN}}$ & 0.0326 & -0.6338 & & & \\
& $(0.83)$ & $(-0.15)$ & 44 & 0.05 & 2.38 \\
$\mathrm{R}_{\mathrm{GVN}}$ & -0.0007 & 1.4269 & & & \\
& $(-0.10)$ & $(1.54)$ & & &
\end{tabular}

The results are quite similar to the monthly returns, where stock returns are negatively related to inflation and gold is also found to be positively correlated with inflation. Furthermore, the coefficient for gold returns is greater than 1.0. On the other hand, the results indicate a positive relationship between real estate returns and inflation for both Thai real estate categories. Unfortunately, all coefficients are statistically insignificant.

Table 4 reports the regression results for the stock, gold and real estate returns on both expected and unexpected inflation rates. From panel A, it can be seen that the regression coefficients on stock returns for both the expected and the unexpected Thai inflation are negative but insignificant, indicating that stocks in Thailand are no hedge against inflation. For Vietnamese stock returns, the coefficient is positive and close to 1.0 for expected inflation, but negative for the unexpected component. Although both coefficients are again not statistically significant, the results imply that stock returns seem to move one-for-one with expected inflation while they react negatively to unexpected inflation. In other words, stocks possibly provide a hedge against expected inflation, but not against unexpected inflation.

Results for gold returns with the contemporaneous inflation show a positive coefficient for expected inflation and a negative coefficient for unexpected inflation, but both coefficients are not statistically significant. However, the coefficient between gold returns and the lead-2 inflation term is positive for both components of inflation. Moreover, it is significant at the $5 \%$ level for expected inflation. The results are obviously consistent with the regression results for total inflation rates, which supports our conjecture above. Regression results for quarterly returns of stock, gold and real estate are shown in panel B. The results generally go in the same direction as those for month returns, i.e., Thai stock returns are negatively related to both components of inflation, while Vietnamese stock returns are positively correlated with expected inflation but negatively related to unexpected inflation. Gold returns have a positive correlation with both expected and unexpected inflation. While both real estate index returns are positively related to unexpected inflation, only the single-detached house index is positively correlated with expected component of inflation. Yet, all coefficients are statistically insignificant. 
Table 4. Regression results of stocks returns, gold returns, real estate returns on both expected and unexpected inflation rates

The table reports the regression results of stock returns, gold returns, real estate returns on both expected and unexpected inflation rates at the contemporaneous terms, also presented below for convenience. In the table, $\mathrm{R}_{\mathrm{STL}}$ denotes the stock returns of Thailand; $R_{R S T L}$ is the returns on single detached houses of Thailand; $R_{R T T L}$ is the returns on town houses with land of Thailand; $R_{\mathrm{SVN}}$ symbolizes the stock returns of Vietnam; $R_{\mathrm{GVN}}$ is the gold returns of Vietnam; $\pi_{\mathrm{t}}$ is the actual inflation rate at time $t$; Inflation rates at time $t$ are defined as changes in $\log$ of the Consumer Prices Index from time ( $t-1)$ to t. Expected and unexpected inflation rates of both countries are decomposed from the actual inflation rates by using Autoregressive (AR) models, where expected inflation rates $\left[E\left(\pi_{t}\right)\right]$ are the linear prediction of the AR model and unexpected inflation rates $\left[U E\left(\pi_{t}\right)\right]$ are the residuals of the AR model. For monthly inflation rates, Vietnam $\left(\pi_{t}=0-\right.$ $\left.0.2049 \pi_{t-1}-0.1097 \pi_{t-11}+0.4916 \pi_{t-12}\right)$ and Thailand

$\left(\pi_{t}=0.0014+0.2779 \pi_{t-1}+0.0325 \pi_{t-11}+0.2240 \pi_{t-12}\right)$; For quarterly inflation rates, Vietnam $\left(\pi_{t}=0.0006-\right.$ $\left.0.4787 \pi_{t-3}\right)$ and Thailand $\left(\pi_{t}=0.0068+0.2526 \pi_{t-4}\right) .\left({ }^{* *}\right),\left({ }^{* *}\right)$ and $(*)$ indicate significance at $1 \%, 5 \%$ and $10 \%$ levels, respectively; the robust $\mathrm{t}$-values are shown in parentheses.

$$
R_{i t}=\alpha_{i}+\beta_{i} E\left(\pi_{t}\right)+\gamma_{i} U E\left(\pi_{t}\right)+n_{t}
$$

\begin{tabular}{lcccccc}
\hline Panel A. Monthly data & \multicolumn{7}{c}{$\gamma_{i}$} & $\beta_{i}$ & $\gamma_{i}$ & $N$ & $\bar{R}^{2}$ & $F$ \\
\hline $\mathrm{R}_{\mathrm{STL}}$ & $0.0192^{*}$ & -3.0135 & -1.1670 & 299 & 0.01 & 0.94 \\
& $(1.87)$ & $(-1.06)$ & $(-0.76)$ & & & \\
$\mathrm{R}_{\mathrm{SVN}}$ & 0.0005 & 1.4096 & -1.8613 & 125 & 0.01 & 0.79 \\
& $(0.04)$ & $(0.59)$ & $(-1.09)$ & & & \\
$\mathrm{R}_{\mathrm{GVN}}$ & -0.0002 & 0.1565 & -0.0622 & 125 & 0.00 & 0.04 \\
& $(-0.05)$ & $(0.25)$ & $(-0.10)$ & & & \\
\hline
\end{tabular}

Panel B. Quarterly data

\begin{tabular}{lcccccc}
\hline & $\alpha_{i}$ & $\beta_{i}$ & $\gamma_{i}$ & $N$ & $\bar{R}^{2}$ & $F$ \\
\hline $\mathrm{R}_{\mathrm{STL}}$ & 0.0431 & -1.6699 & -0.2954 & 96 & 0.00 & 0.05 \\
& $(0.66)$ & $(-0.24)$ & $(-0.15)$ & & & \\
$\mathrm{R}_{\mathrm{RSTL}}$ & -0.0049 & 0.4013 & 0.6495 & 75 & 0.01 & 0.76 \\
& $(-0.22)$ & $(0.22)$ & $(1.19)$ & & & \\
$\mathrm{R}_{\mathrm{RTTL}}$ & 0.0005 & -0.1131 & 0.5994 & 75 & 0.01 & 0.71 \\
& $(0.03)$ & $(-0.08)$ & $(1.18)$ & & & \\
$\mathrm{R}_{\mathrm{SVN}}$ & 0.0081 & 13.6011 & -4.7740 & 43 & 0.06 & 1.13 \\
& $(0.20)$ & $(1.38)$ & $(-0.83)$ & & & \\
$\mathrm{R}_{\mathrm{GVN}}$ & -0.0010 & 2.9796 & 0.9570 & 43 & 0.07 & 1.66 \\
& $(-0.13)$ & $(1.64)$ & $(1.00)$ & & & \\
\hline
\end{tabular}

\subsection{Stability Analyses}

Structural changes may occur in time series due to economic shocks, market crises and various institutional reforms. Such episodes, if not taken into account, may induce structural shifts and bias the estimated results (Alagidede and Panagiotidis, 2010; Worthington and Pahlavani, 2007).

Specifically, some significant institutional changes on the Vietnamese stock market should be considered. Since March 2002, the market has started daily trading while prior only 3 trading days per week were organized. Another possible break point is around the beginning of 2006 when several important institutional reforms were undertaken. From 2006 onwards, foreign investors were allowed to hold up to 49\% ownership of a Vietnamese listed non-financial firm. In addition to, in the same year, the Hanoi stock exchange was in effect launched for trading. The joint effects of these facts significantly impact the stock market in terms of its liquidity and market capitalization. 
Taking these structural changes into account, we exogenously divide the sample into three subsamples with two break points to check for the stability of the stock return-inflation relationship in Vietnam.

For Thailand, we divide our sample into 4 subsamples. The first period from February 1987 till June 1997 as the pre-financial crisis period, when Thailand achieved strong economic growth and was recognized as one of the world's fastest growing economies (Endo, 2000). The second period covers the financial crisis, but we extend it until July 2003 since it may better reflect the severe macroeconomic conditions in Thailand. Even after July 1998, Thai macroeconomic policy was still under tight supervision of the International Monetary Fund (IMF). This may have influenced economic activity. In July 2003, Thailand was completely free from its financial obligations to the IMF. For the rest of the sample, we use January 2009 as a break point for two reasons. Due to its export-driven characteristics, Thailand severely suffered from the global economic recession starting at the end of 2008. This moment also marked the formation of an official government after about two years of political turmoil in the country. Table 5 presents the summary of regression coefficients between stock returns, gold returns, real estate returns and actual inflation for the whole sample and all subsamples.

In panel A, we show the results for monthly returns. For Thai stocks, the negative coefficient found in the first two subsamples turns positive for the last two subsamples. It should be noted that the coefficient for the second subsample, i.e., the financial crisis period, is very large and significantly negative at the $5 \%$ level, while the coefficients for the last two subsamples are small and almost equal. Most coefficients for Vietnamese stock returns are statistically insignificant and negative. Only the coefficient for the second subsample turns positive and greater than 1.0, but is still statistically insignificant. For gold, the coefficient on contemporaneous inflation is found to be negative in the second subsample while those of the other two subsamples remain positive. Noticeably, the regression coefficient between gold returns and lead- 2 inflation is significantly positive at the $10 \%$ level for the last subsample.

In panel $\mathrm{B}$, the regression coefficients for quarterly returns and inflation are summarized. A similar pattern for the coefficients in the subsamples is found for Thai stock returns, except that the coefficient for the last subsample becomes negative. The two kinds of housing show a similar correlation with inflation over time: coefficients are only negative in the first subsample and positive for the other subsamples. For Vietnam, results for stock returns are also similar to those for monthly stock returns, except for the first subsample where a positive coefficient is observed. Finally, coefficients for gold returns are consistently found to be positive across all subsamples. A summary of the regression coefficients of stock returns, gold returns, and real estate returns on both expected and unexpected inflation is shown in Table 6, where the coefficients for monthly returns and quarterly returns are presented in panel A and panel B respectively.

The monthly Thai stock returns are insignificantly negatively correlated with expected inflation in the first three subsamples, while positively related to expected inflation in the last subsample. However, the relationship between stock returns and unexpected inflation is found to be negative in the first two subsamples and positive in subsamples 3 and 4 . It is large and significantly negative at the $10 \%$ level in the second subsample. The results indicate that monthly Vietnamese stock returns are negatively related in the first subsample and positively related in the second subsample to both components of inflation. In the last subsample, stock returns have a positive relationship to expected inflation and a negative correlation with unexpected inflation. Regarding monthly gold returns, a positive relation to expected inflation is observed in the subsample 2 and 3 , whereas it is negative in the first subsample.

Several observations can be made from the results for quarterly returns. Stock returns in Thailand are significantly and strongly related to expected inflation in the first subsample. The relationship is positive in the subsamples 2 and 4, but negative in subsample 3. Considering the relationship between the real estate returns and inflation, both types of real estate tend to react similarly to inflation in all subsamples. Specifically, both returns are positively correlated to expected inflation and negatively related to unexpected inflation in the first subsample. In contrast, they are negatively related to expected inflation but positively related to unexpected inflation in the second subsample. In the last subsample, their relationship to both components of inflation is positive. Yet, in the third subsample, although they both are positively related to the unexpected inflation, the single-detached house returns are negatively related to expected inflation whereas town house returns show a positive correlation to expected inflation. For Vietnam, stock returns are positively correlated to expected inflation in subsample 2 and 3 , while the relationship is negative in the first subsample. Also, stock returns are positively related to unexpected inflation in subsample 1 and 2, whereas the relationship is statistically negative in subsample 3 . Gold returns indicate a consistently positive correspondence with both components of inflation in all cases, except that a negative coefficient on expected inflation is observed in 
subsample 1. Consistent with the results above, gold returns consistently show a statistically positive correlation with either expected inflation or unexpected inflation for the $2^{\text {nd }}$ and $3^{\text {rd }}$ subsamples.

Table 5. Summary of regressions results between stock returns, gold returns and real estate returns and actual inflation for whole sample and subsamples

The table summarizes the regression coefficients of stock returns, gold returns, real estate returns on actual inflation rates $\left(\beta_{i}\right)$ [equation (4)], also presented below for convenience, for whole sample and subsamples. Detailed results of all regressions for subsamples are reported in the table. $R_{i t}$ represents the returns on asset $\mathrm{i} ; \pi_{t}$ is the inflation rate at time $t .\left({ }^{* *}\right),\left({ }^{* *}\right)$ and $(*)$ indicate significance at $1 \%, 5 \%$ and $10 \%$ level, respectively; the robust $\mathrm{t}$-values are shown in the parentheses.

$$
R_{i t}=\alpha_{i}+\beta_{i} \pi_{t}+\varepsilon_{t}
$$

\begin{tabular}{|c|c|c|c|c|c|}
\hline \multicolumn{6}{|l|}{ Panel A. Monthly data } \\
\hline \multicolumn{2}{|l|}{ Assets returns } & \multicolumn{2}{|c|}{ Coefficients $(\beta)_{i}$} & \multirow{3}{*}{$\begin{array}{r}\text { 2003M8 } \\
-2008 \mathrm{M} 12\end{array}$} & \multirow{3}{*}{$\begin{array}{r}2009 \mathrm{M} 1 \\
-2011 \mathrm{M} 12\end{array}$} \\
\hline \multirow{2}{*}{ Thailand } & Whole & $1987 \mathrm{M} 2$ & 1997M7 & & \\
\hline & sample & -1997M6 & $-2003 \mathrm{M} 7$ & & \\
\hline Stocks returns & -1.4263 & -1.378 & $-7.7362 * *$ & 0.6451 & 0.6232 \\
\hline \multirow{2}{*}{ Vietnam } & Whole & 2000M8 & 2002M3 & 2006M1 & \\
\hline & sample & $-2002 \mathrm{M} 2$ & $-2005 \mathrm{M} 12$ & $-2011 \mathrm{M} 12$ & \\
\hline Stocks returns & -0.3199 & -5.0479 & 1.4528 & -1.424 & \\
\hline Gold returns & 0.0428 & 1.4528 & -0.1965 & 0.2232 & \\
\hline Gold returns $\left(\pi_{\mathrm{t}+2}\right)$ & $0.9326^{* *}$ & -0.0781 & 0.958 & $1.1882 *$ & \\
\hline \multicolumn{6}{|l|}{ Panel B. Quarterly data } \\
\hline \multicolumn{2}{|l|}{ Assets returns } & \multicolumn{2}{|c|}{ Coefficients $\left(\beta_{i}\right)$} & & \\
\hline \multirow{2}{*}{ Thailand } & Whole & 1987Q1 & 1997Q3 & 2003Q4 & 2009Q1 \\
\hline & sample & $-1997 Q 2$ & $-2003 Q 3$ & $-2008 Q 4$ & $-2011 Q 4$ \\
\hline Stocks returns & -0.3065 & -3.4341 & -5.5839 & 2.5396 & -3.2736 \\
\hline Single- houses returns & 0.6347 & -0.7356 & 0.7997 & 0.0761 & 11.0362 \\
\hline Town houses returns & 0.5568 & -0.678 & 0.8921 & 0.0401 & 8.6557 \\
\hline \multirow{2}{*}{ Vietnam } & Whole & 2000Q2 & 2002Q2 & 2006Q1 & \\
\hline & sample & $-2002 Q 1$ & $-2005 \mathrm{Q} 4$ & $-2011 Q 4$ & \\
\hline Stocks returns & -0.6338 & 7.623 & 11.7101 & -4.5538 & \\
\hline Gold returns & 1.4269 & 0.051 & $2.2659^{*}$ & 1.6221 & \\
\hline
\end{tabular}


Table 6. Summary of regression results between stock returns, gold returns, real estate returns and both components of inflation for whole sample and subsamples

The table summarizes the regression coefficients of stock returns, gold returns, real estate returns on both expected and unexpected inflation rates ( $\beta_{i}$ and $\gamma_{i}$, respectively) at the contemporaneous terms [equation (5)], also presented below for convenience, for whole sample and subsamples. Detailed results of all regressions for subsamples are reported in the table. Expected and unexpected inflation rates of both countries are decomposed from the actual inflation rates by using Autoregressive (AR) models, where expected inflation rates $\left[E\left(\pi_{t}\right)\right]$ are the linear prediction of the AR model and unexpected inflation rates $\left[U E\left(\pi_{t}\right)\right]$ are the residuals of the AR model. For monthly inflation rates, Vietnam $\left(\pi_{t}=0-\right.$ $\left.0.2049 \pi_{t-1}-0.1097 \pi_{t-11}+0.4916 \pi_{t-12}\right) \quad$ and Thailand $\quad\left(\pi_{t}=0.0014+0.2779 \pi_{t-1}+0.0325 \pi_{t-11}+\right.$ $\left.0.2240 \pi_{t-12}\right)$; For quarterly inflation rates, Vietnam $\left(\pi_{t}=0.0006-0.4787 \pi_{t-3}\right)$ and Thailand $\left(\pi_{t}=0.0068+\right.$ $\left.0.2526 \pi_{t-4}\right) .\left({ }^{* *}\right),\left({ }^{* *}\right)$ and $(*)$ indicate significance level at $1 \%, 5 \%$ and $10 \%$ levels, respectively; the robust t-values are shown in the parentheses. $R_{i t}=\alpha_{i}+\beta_{i} E\left(\pi_{t}\right)+\gamma_{i} U E\left(\pi_{t}\right)+n_{t}$

\begin{tabular}{|c|c|c|c|c|c|c|}
\hline \multicolumn{7}{|c|}{ Panel A. Monthly data } \\
\hline \multicolumn{3}{|l|}{ Assets returns } & \multicolumn{3}{|c|}{ Coefficients } & \multirow{3}{*}{$\begin{array}{r}2009 \mathrm{M} 1 \\
-2011 \mathrm{M} 12\end{array}$} \\
\hline \multirow{2}{*}{\multicolumn{2}{|c|}{ Thailand }} & Whole & 1987M2 & 1997M7 & 2003M8 & \\
\hline & & sample & $-1997 \mathrm{M} 6$ & $-2003 \mathrm{M} 7$ & $-2008 \mathrm{M} 12$ & \\
\hline \multirow{2}{*}{ Stocks returns } & $\beta_{i}$ & -3.0135 & -6.7056 & -9.7076 & -3.5166 & 5.7453 \\
\hline & $\gamma_{i}$ & -1.167 & -0.7174 & $-7.4343^{*}$ & 1.3687 & 0.0138 \\
\hline \multirow{2}{*}{\multicolumn{2}{|c|}{ Vietnam }} & Whole & 2000M8 & $2002 \mathrm{M} 3$ & 2006M1 & \\
\hline & & sample & $-2002 \mathrm{M} 2$ & $-2005 \mathrm{M} 12$ & $-2011 \mathrm{M} 12$ & \\
\hline \multirow[t]{2}{*}{ Stocks returns } & $\beta_{i}$ & 1.4096 & -6.4968 & 0.4834 & 0.8045 & \\
\hline & $\gamma_{i}$ & -1.8613 & -9.2819 & 2.4863 & -2.3477 & \\
\hline \multirow[t]{2}{*}{ Gold returns } & $\beta_{i}$ & 0.1565 & $-6.4807 *$ & 0.3079 & 0.5277 & \\
\hline & $\gamma_{i}$ & -0.0622 & -1.1123 & -0.7342 & 0.0970 & \\
\hline \multirow[t]{2}{*}{ Gold returns $\left(\pi_{\mathrm{t}+2}\right)$} & $\beta_{i}$ & $1.6962 * *$ & -0.2319 & 0.3974 & $2.7309 * *$ & \\
\hline & $\gamma_{i}$ & 0.4713 & 0.0383 & $1.7769^{*}$ & 0.5829 & \\
\hline \multicolumn{7}{|c|}{ Panel B. Quarterly data } \\
\hline \multicolumn{3}{|l|}{ Assets returns } & \multicolumn{2}{|c|}{ Coefficients } & & \\
\hline \multirow{2}{*}{\multicolumn{2}{|c|}{ Thailand }} & Whole & 1987Q1 & 1997Q3 & 2003Q4 & 2009Q1 \\
\hline & & sample & $-1997 Q 2$ & $-2003 Q 3$ & $-2008 Q 4$ & $-2011 Q 4$ \\
\hline \multirow[t]{2}{*}{ Stocks returns } & $\beta_{i}$ & -1.6699 & $-31.1186^{*}$ & 7.3399 & -4.8261 & 2.675 \\
\hline & $\gamma_{i}$ & -0.2954 & -0.2833 & -5.8336 & 2.7369 & -7.585 \\
\hline \multirow[t]{2}{*}{ Single houses returns } & $\beta_{i}$ & 0.4013 & 1.578 & -2.9525 & -0.515 & 8.0355 \\
\hline & $\gamma_{i}$ & 0.6495 & -1.2921 & 0.8721 & 0.0919 & 13.211 \\
\hline \multirow[t]{2}{*}{ Town houses returns } & $\beta_{i}$ & -0.1131 & 0.9289 & -2.9682 & 0.0635 & 5.7769 \\
\hline & $\gamma_{i}$ & 0.5994 & -1.0645 & 0.9666 & 0.0395 & 10.742 \\
\hline \multirow{2}{*}{\multicolumn{2}{|c|}{ Vietnam }} & Whole & 2000Q2 & 2002Q2 & 2006Q1 & \\
\hline & & sample & $-2002 Q 1$ & -2005 Q4 & $-2011 Q 4$ & \\
\hline \multirow[t]{2}{*}{ Stocks returns } & $\beta_{i}$ & 13.6011 & -9.6398 & 16.8098 & 16.3287 & \\
\hline & $\gamma_{i}$ & -4.774 & 10.9783 & 10.2205 & $-11.2161^{*}$ & \\
\hline \multirow[t]{2}{*}{ Gold returns } & $\beta_{i}$ & 2.9796 & -4.1067 & 3.0096 & 3.7089 & \\
\hline & $\gamma_{i}$ & 0.957 & 0.3002 & 2.0487 & 0.9563 & \\
\hline
\end{tabular}




\section{Conclusions}

Although Thai and Vietnamese stock returns are negatively correlated with the actual inflation rates, the relationship is not statistically significant. Decomposing the actual inflation rates into an expected and an unexpected component, we find that Thai stock returns are negatively related to both components. In contrast, for Vietnamese stock returns the coefficients for expected inflation are greater than 1.0 and thus indicate a positive relation, whereas stock returns are negatively related to unexpected inflation. However, again the coefficients are not statistically significant.

We also exogenously split the sample into subsamples and re-estimate the regressions as a robustness check for our findings. We found a large and significantly negative relationship between monthly stock returns and inflation during the financial crisis period for Thailand, although the coefficients are still not statistically significant and change signs in some cases for the other subsamples. For Vietnam, although the coefficient's sign is positive in some cases, it remains insignificant across all subsamples.

Interestingly, while stock returns are found to be negatively related to actual inflation, gold returns (Vietnam) and real estate returns (Thailand) generally show a positive relationship with actual inflation. Particularly, gold returns are, though not statistically significantly, positively related to actual inflation rates as well as to both expected and unexpected inflation. The relationship is greater than 1.0 in some cases. Regarding the hedging ability of real estate returns, only one of the two Thai real estate returns shows a positive relationship with both components of inflation, i.e., single-detached-house returns. The town-house-with-land returns are negatively correlated with expected inflation but positively related to unexpected inflation. However, we do not find any statistically significant relationship between gold returns or real estate returns and actual inflation nor with its components, i.e., expected and unexpected inflation. Moreover, the coefficient stability checks indicate mixed results for both countries regarding the hedging ability of gold and real estate.

Noticeably, we consistently find a significantly greater-than-unity relationship between monthly gold returns and the lead-2 term of actual inflation, expected inflation and unexpected inflation for the whole sample. Taking the real economic situation of the country into account, it could be that gold provides a good hedge against inflation in Vietnam.

To sum up, we do not find evidence in favor of the Fisher effect in Thai or Vietnamese stock returns. For gold and real estate returns we find relatively consistent positive correlations with inflation but we cannot statistically support the Fisher hypothesis for these asset returns with the data at hand.

\section{References}

Adrangi, Bahram, Arjun Chatrath, \& Kambiz Raffiee. (2003). Economic Activity, Inflation, and Hedging. The Journal of Wealth Management, 6, 60-77. http://dx.doi.org/10.3905/jwm.2003.320482

Akaike, H. (1974). A new look at the statistical model identification. Automatic Control, IEEE Transactions on, 19, 716-723. http://dx.doi.org/10.1109/TAC.1974.1100705

Al-Khazali, O.M., \& C.S. Pyun. (2004). Stock prices and inflation: new evidence from the Pacific-Basin countries. Review of Quantitative Finance and Accounting, 22, $123-140$. http://dx.doi.org/10.1023/B:REQU.0000015853.16564.e3

Alagidede, P. (2009). Relationship between stock returns and inflation. Applied Economics Letters, 16, $1403-1408$.

Alagidede, P., \& T. Panagiotidis. (2010). Can common stocks provide a hedge against inflation? Evidence from African countries. Review of Financial Economics, 19, 91-100. http://dx.doi.org/10.1016/j.rfe.2010.04.002

Ang, A., G. Bekaert, \& M. Wei. (2007). Do macro variables, asset markets, or surveys forecast inflation better? Journal of Monetary Economics, 54, 1163-1212. http://dx.doi.org/10.1016/j.jmoneco.2006.04.006

Barber, C., D. Robertson, \& A. Scott. (1997). Property and Inflation: the hedging characteristics of UK commercial property, 1967-1994. The Journal of Real Estate Finance and Economics, 15, 59-76.

Boudoukh, J., \& M. Richardson. (1993). Stock returns and inflation: A long-horizon perspective. The American Economic Review, 83, 1346-1355.

Box, G. E. P., \& G. M. Jenkins. (1970). Time Series Analysis, Forecasting and Control. Holden Day, San Francisco.

Brennan, M.J., \& E.S. Schwartz. (1978). Corporate income taxes, valuation, and the problem of optimal capital structure. Journal of Business, 103-114. http://dx.doi.org/10.1086/295987 
Brueggeman, W.B., A.H. Chen, \& T.G. Thibodeau. (1984). Real estate investment funds: Performance and portfolio considerations. Real Estate Economics, 12, 333-354. http://dx.doi.org/10.1111/1540-6229.00326

Charles, W.H., M.R. Glenn, \& M. Donna. (1991). The impact of inflation and vacancy of real estate returns. Journal of Real Estate Research, 6, 153-168.

Chatrath, A., S. Ramchander, \& F. Song. (1997). Stock prices, inflation and output: evidence from India. Applied Financial Economics, 7, 439-445. http://dx.doi.org/10.1080/096031097333556

Choudhry, T. (2001). Inflation and rates of return on stocks: evidence from high inflation countries. Journal of International Financial Markets, Institutions and Money, 11, 75-96. http://dx.doi.org/10.1016/S1042-4431(00)00037-8

Chu, Y. Q., \& Tien.F. Sing. (2003). Inflation hedging characteristics of Chinese real estate market. Journal of Economic Studies, 16(2), 3-13.

Chua, J., \& R.S. Woodward. (1982). Gold as an inflation hedge: a comparative study of six major industrial countries. Journal of Business Finance \& Accounting, 9, 191-197. http://dx.doi.org/10.1111/j.1468-5957.1982.tb00985.x

Cohn, R.A., \& D.R. Lessard. (1981). The effect of inflation on stock prices: international evidence. The Journal of Finance, 36, 277-289. http://dx.doi.org/10.1111/j.1540-6261.1981.tb00440.x

Crosby, M. (2001). Stock returns and inflation. Australian Economic Papers, 40, 156-165.

Dickey, D.A., \& W.A. Fuller. (1979). Distribution of the estimators for autoregressive time series with a unit root. Journal of the American statistical association, 427-431.

Ely, D.P., \& K.J. Robinson. (1997). Are stocks a hedge against inflation? International evidence using a long-run approach. Journal of International Money and Finance, 16, 141-167. http://dx.doi.org/10.1016/S0261-5606(96)00039-3

Endo, T. (2000). Thailand: Selected Issues. International Monetary Fund.

Engsted, T., \& C. Tanggaard. (2002). The relation between asset returns and inflation at short and long horizons. Journal of International Financial Markets, Institutions and Money, 12, 101-118.

Fama, E.F., \& G.W. Schwert. (1977). Asset returns and inflation. Journal of Financial Economics, 5, 115-146.

Firth, M. (1979). The relationship between stock market returns and rates of inflation. The Journal of Finance, 34, 743-749. http://dx.doi.org/10.1111/j.1540-6261.1979.tb02139.x

Fisher, Irving. (1930). The Theory of Interest. MacMillan, New York.

Floros, C. (2008). Stock returns and inflation in Greece. Applied Econometrics and International Development, 4(2), 2004.

Fogler, H.R., M.R. Granito, \& R.S. Laurence. (1985). A theoretical analysis of real estate returns. Journal of Finance, 40, 711-719. http://dx.doi.org/10.1111/j.1540-6261.1985.tb04994.x

Ganesan, S., \& YH Chiang. (1998). The inflation-hedging characteristics of real and financial assets in Hong Kong. Journal of Real Estate Portfolio Management, 4, 55-67.

Ghosh, D., E.J. Levin, P. Macmillan, \& R.E. Wright. (2004). Gold as an inflation hedge? Studies in Economics and Finance, 22, 1-25. http://dx.doi.org/10.1108/eb043380

Glascock, J., L. Feng, L. Fan, \& H. Bao. (2008). Inflation Hedging Characteristics of Real Estate Assets in Hong Kong.

Gultekin, N.B. (1983). Stock market returns and inflation: Evidence from other countries. Journal of Finance, 49-65.

Hamelink, F., \& M. Hoesli. (1996). Swiss real estate as a hedge against inflation: new evidence using hedonic and autoregressive models. Journal of Property Finance, 7, 33-49. http://dx.doi.org/10.1108/09588689610111601

Harmston, S. (1998). Gold as a Store of Value. Centre for Public Policy Studies, The World Gold Council.

Hartzell, D., J.S. Hekman, \& M.E. Miles. (1987). Real estate returns and inflation. Real Estate Economics, 15, 617-637. http://dx.doi.org/10.1111/1540-6229.00407

Hoesli, M. (1994). Real estate as a hedge against inflation: learning from the Swiss case. Journal of Property Valuation and Investment, 12, 51-59. http://dx.doi.org/10.1108/14635789410063913 
Hondroyiannis, G., \& E. Papapetrou. (2006). Stock returns and inflation in Greece: A Markov switching approach. Review of Financial Economics, 15, 76-94. http://dx.doi.org/10.1016/j.rfe.2005.02.002

Khil, J., \& B.S. Lee. (2000). Are common stocks a good hedge against inflation? Evidence from the Pacific-rim countries. Pacific-Basin Finance Journal, 8, 457-482. http://dx.doi.org/10.1016/S0927-538X(00)00019-6

Kim, J.H., \& H.H. Ryoo. (2011). Common stocks as a hedge against inflation: Evidence from century-long US data. Economics Letters, 113, 168-171. http://dx.doi.org/10.1016/j.econlet.2011.07.003

Kwiatkowski, D., P.C.B. Phillips, P. Schmidt, \& Y. Shin. (1992). Testing the null hypothesis of stationarity against the alternative of a unit root 1: How sure are we that economic time series have a unit root? Journal of econometrics, 54, 159-178. http://dx.doi.org/10.1016/0304-4076(92)90104-Y

Laurent, R.D. (1994). Is there a role for gold in monetary policy? Economic Perspectives, 2-14.

Levin, E.J., A. Montagnoli, \& RE Wright. (2006). Short-run and Long-run Determinants of the Price of Gold. World Gold Council.

Li, L., P.K. Narayan, \& X. Zheng. (2010). An analysis of inflation and stock returns for the UK. Journal of International Financial Markets, Institutions and Money, 20, 519-532. http://dx.doi.org/10.1016/j.intfin.2010.07.002

Lintner, J. (1975). Inflation and security returns. The Journal of Finance, 30, 259-280.

Mahmood, WMW, \& N.M. Dinniah. (2009). Stock Returns and Macroeconomic Influences: Evidence from the Six Asian-Pacific Countries. International Research Journal of Finance and Economics, 30, 154-64.

Miles, D. (1996). Property and inflation. Journal of Property Finance, 7, 21-32. http://dx.doi.org/10.1108/EUM0000000000001

Moore, G.H. (1990). ANALYSIS: Gold Prices and a Leading Index of Inflation. Challenge, 33, 52-56.

Najand, M., \& G. Noronha. (1998). Causal relations among stock returns, inflation, real activity, and interest rates: Evidence from Japan. Global Finance Journal, 9, 71-80. http://dx.doi.org/10.1016/S1044-0283(98)90015-1

National, T.F.S., \& S.H.Y. Low. (2000). The inflation-hedging characteristics of real estate and financial assets in Singapore. Journal of Real Estate Portfolio Management, 6, 373-385.

Omran, M., \& J. Pointon. (2001). Does the inflation rate affect the performance of the stock market? The case of Egypt. Emerging Markets Review, 2, 263-279. http://dx.doi.org/10.1016/S1566-0141(01)00020-6

Plasmans, J. (2006). Modern linear and nonlinear econometrics. Springer Verlag.

Sim, S. H. \& J. I. Choe. (2002). An Investigation of the Inflation-Hedging Ability of Housing and Stock Returns in Korea, 135-151.

Sing, T.F, \& S.H.Y. Low. (2000). The inflation-hedging characteristics of real estate and financial assets in Singapore. Journal of Real Estate Portfolio Management, 6, 373-385.

Solnik, B. (1983). The relation between stock prices and inflationary expectations: the international evidence. Journal of Finance, 35-48. http://dx.doi.org/10.1111/j.1540-6261.1983.tb03624.x

Spyrou, S.I. (2004). Are stocks a good hedge against inflation? Evidence from emerging markets. Applied Economics, 36, 41-48. http://dx.doi.org/10.1080/0003684042000177189

Stevenson, S., \& Murray, L. (1999). An examination of the inflation hedging ability of Irish real estate. Journal of Real Estate Portfolio Management, 5, 59-69.

Subhanij, T. (2009). Household sector and monetary policy implications: Thailand's recent experience. Bank for International Settlements, 136.

Taylor, N.J. (1998). Precious metals and inflation. Applied Financial Economics, 8, 201-210.

Vuong, Q.H. (2004). Analyses on Gold and US Dollar in Vietnam's Transitional Economy. ULB-Universite Libre de Bruxelles.

Wahlroos, B., \& T. Berglund. (1986). Stock returns, inflationary expectations and real activity: New evidence. Journal of Banking \& Finance, 10, 377-389. http://dx.doi.org/10.1016/S0378-4266(86)80027-9

White, H. (1980). A heteroskedasticity-consistent covariance matrix estimator and a direct test for heteroskedasticity. Econometrica: Journal of the Econometric Society, 817-838. http://dx.doi.org/10.2307/1912934 
Worthington, A.C., \& M. Pahlavani. (2007). Gold investment as an inflationary hedge: Cointegration evidence with allowance for endogenous structural breaks. Applied Financial Economics Letters, 3, 259-262. http://dx.doi.org/10.1080/17446540601118301

Zhao, X.Q. (1999). Stock prices, inflation and output: evidence from China. Applied Economics Letters, 6, 509-511. http://dx.doi.org/10.1080/135048599352835

\section{Notes}

Note 1. "Greenspan Takes the Gold" (The Wall Street Journal, Feb. 28, 1994).

Note 2. Daily markets: http://www.dailymarkets.com/economy/2010/06/18/vietnam-increasing-investment-in-gold

Note 3. http://www.northamericaninterests.ca/gold-in-2011.php

Note 4. Vietnam Gold Trading Association.

Note 5. Stationarity of all variables is checked by both the Augmented Dickey-Fuller unit root test (ADF) (Dickey and Fuller, 1979) and the KPSS stationarity test (Kwiatkowski, Phillips, Schmidt and Shin, 1992), since the use of the KPSS test where the null hypothesis is the stationary time series can circumvent the problem of low power of the unit root ADF test (Plasmans, 2006). Optimal lag length selection for these tests is based on the Akaike Information Criterion (AIC) (Akaike, 1974). In fact, we also checked with and Schwartz (Bayesian) Information Criterion (BIC, SC, SBC) by (Brennan and Schwartz, 1978) and this did not change our conclusion that all the time series are stationary. Results are available upon request.

Note 6. Autoregressive models are utilized to decompose the actual inflation into expected and unexpected inflation. The number of lags for each model is derived from the autocorrelation tests for actual inflation series. In particular, we employ the AR(4) and AR(3) for the quarterly inflation rates of Thailand and Vietnam, respectively. For monthly inflation rates, AR with three lags 1,11 and 12 is applied for both countries. The Ljung-Box Portmanteau (Q) test finds no evidence of remaining residual serial correlation. Only the Vietnamese monthly inflation rates series requires higher AR-orders. Yet, the short time series of monthly inflation of Vietnam renders us to use longer lag length in the AR model to decompose inflation for the country. 